\title{
Weed Allelochemicals and Possibility for Pest Management
}

\section{Tran Dang Xuan ${ }^{1, a^{*}}$, La Hoang Anh ${ }^{1, b}$, Do Tan Khang ${ }^{1, c}$, Phung Thi Tuyen ${ }^{1, d}$, Truong Ngoc Minh ${ }^{1, e}$, Tran Dang Khanh ${ }^{2, f}$, Khuat Huu Trung ${ }^{2, g}$}

\author{
${ }^{1}$ Division of Development Technology, Graduate School for International Cooperation and \\ Development, Hiroshima University, 739-8529, Japan \\ ${ }^{2}$ Agricultural Genetics Institute, Ha Noi, Vietnam \\ atdxuan@hiroshima-u.ac.jp, bhoanganh6920@gmail.com, 'cdtkhang@ctu.edu.vn, \\ dphungtuyen@gmail.com, ${ }^{\mathrm{d}}$ minhtn689@gmail.com, 'khanhkonkuk@gmail.com, \\ gkhuathuutrung@yahoo.com \\ ${ }^{*}$ Corresponding author: tdxuan@hiroshima-u.ac.jp
}

\begin{abstract}
Keywords: Allelopathy; allelochemicals; natural pesticide; sustainable agriculture; pest management; weed interaction
\end{abstract}

\begin{abstract}
Purpose: Weed interference is a constraint in agricultural practice. The crop-weed interaction has been extensively described in literature, but the weed-weed interaction and their potential usage in crop production have not much been understood. In this paper, the interactions of allelochemicals of the weeds which cause troublesome in crop production and ecosystem against weeds, crops, and pathogens are described.

Principal results: Weed allelochemicals are classified into many chemical classes, and the majority is consisting of phenolics acids, alkaloids, terpenes, flavonoids, long chain fatty acids, lactones, and other volatile compounds. Type of weed allelochemicals and their doses are varied among weed species. Some allelochemicals such as catechin (+/-) have been reported to be responsible for weed invasiveness. Some crops exude germination stimulants to parasitic weeds such as Striga spp. and Orobanche spp. In contrast to their negative impacts on crop production, many weeds can be exploited as promising sources to control harmful insects, fungi, bacteria, and weeds. For instance, Ageratum conyzoides is a destructive weed in crop production, but it exerted excellent insecticidal, antifungal, and herbicidal capacity and promoted citrus productivity in $A$. conyzoides intercropped citrus orchards.

Major conclusions: In general, weeds compete with crops by chemical pathway by releasing plant growth inhibitors to reduce crop growth. Weed allelochemicals may be successfully exploited for pest and weed controls in an integrated sustainable crop production. Some weed allelochemicals are potent for development of natural pesticides.
\end{abstract}

\section{Introduction}

Weed interference includes both competition and allelopathy. The competition consists of water, light, nutrients, spaces, and under certain conditions, carbon dioxide for photosynthesis. However, weeds also interact with crops and other plants including themselves by chemical pathway (allelopathy). To date, some hundreds weed species worldwide possessed allelopathic potential have been listed, of which 240 weed species are reported to exhibit inhibitory activity against crop plants [1]. A number of weed phytotoxins have been found in root exudates, leachates, leaf volatile, decomposition of weed plants, and weed soil. Weed allelochemicals belong to various chemical classes such as phenolic acids, flavonoids, lactones, ketones, coumarins, alcohols, polyphenols, glycosides, alkaloids, aldehydes, and terpenes. To understand the interactions of weeds-crops, weeds-weeds, weeds-plant pathogens, weeds-parasitic weeds, and weed autotoxicity is 
indispensable for weed management. In addition, weed allelochemicals and the syntheses of their derivatives may be potential for the development of bioactive pesticides.

The interaction by chemical pathway (allelopathy) between weeds and crops has been extensively studied, but little is known about how weed allelochemicals interact in environment and agricultural practice, with the involvements of crops, weeds, and pathogens. This study overviews the interference of allelochemicals among weeds, crops, and pathogens and discusses potential uses of weed allelochemicals in pest management to establish a sustainable agricultural production.

\section{Weed interactions}

The weed-crop interaction may result in either positive or negative influence. A great loss of crop yield has caused by weed-crop competition, together with the transference of harmful insects and pathogens to crops. However, legume weeds may be useful for soil improvement which could enhance crop yields. Chemicals released by weeds also play a role by either inhibiting (via growth inhibitors) or stimulating (via growth stimulators such as agrostemmin) crop growth [2,3]. Out of 30,000 plant species identified as weeds, 80 species are reported to reduce crop yield [4]. Qasem and Foy [1] demonstrated 240 weed species of different growth habits and life forms exhibited harmful effects on a wide range of crop species through different mechanisms. These weeds include both aggressive annual or perennial weeds and many world's worst weeds. The interaction among weeds is interesting and allelochemicals released from weeds to inhibit growth of other weeds are expected to be exploited as natural chemicals that may be useful in the development of natural herbicides. Qasem and Foy [1] also described the interactions of 64 weed species as donors on emergence of a number of receiver weeds

Weed allelochemicals could suppress growth of other weeds but showed less effective to itself or other weeds in similar families. We observed that phytotoxins released by barnyardgrass (Echinochloa crus-galli) were much inhibitory against dicot weeds than monocot weeds [5]. Similarly, mimosine, an allelochemical in Leucaena plants and Mimosa spp. species, exerted strong inhibition against growth of several upland and lowland weeds, but it was not suppressive against growth of Mimosa species, as this species is the mimosine producer [6]. For invasive weeds, it was noted that the invasive species inhibited growth of the native species by releasing toxins into the environment such as $(+)$ catechin [7]. Duke et al., in contrast, claimed that $(-)$ catechin is more phytotoxic than $(+)$ catechin [8].

Allelochemicals from weeds also obtain antibacterial and antifungal activities. These compounds were found in plant extracts, residues, leachates, volatiles, and essential oils. Qasem and Foy [1] listed 51 weed species have antimicrobial and antifungal properties. Sources of toxins were from residues, extracts, tuber oils, leachates, and volatiles with different allelochemicals such as phenolics [9], sesquiterpenes [10], phloroglucinol, acetophenone [11], and diterpnes [12].

The interaction between weeds and parasitic weeds was also concerned as the parasitic weeds represent a major threat to agricultural production. It was found that different cultivated species producing ethylene or strigoles that stimulate seed germination of certain parasitic weeds, including different species of Orobanche and Striga. Sorghum, barley, and Vicia dasycarpa spp. villosa stimulated emergence of Orobanche crenata [13,14], whilst bean, sorghum, maize, and cucumber promoted growth of $O$. ramose [15]. The use of a variety of mixtures of plant species is possible to reduce Orobanche-host interaction by combining certain host species with different degrees of susceptibility [16]. Striga seed germination can be suppressed by root exudates of some non-host plants, including cotton root exudates that stimulate $S$. asiatica seed germination. The use of wild species to control parasitic weeds is possible but preliminary screening should be elaborated [1]. 


\section{Weed allelochemicals}

It has been found that any plant part of weeds can possess allelochemicals, despite the quantity may be differed from each part, such as stems, leaves, flowers, buds, bark, pollen grains, seeds, fruits, roots, and rhizomes [17,18]. The mechanisms of allelochemical release in weeds include volatilization from stems and leaves [19], roots [20], shoots [21], pollen [22], fruits [23], flowers [24], and residue decay [25]. Allelochemicals must reach sufficient doses to receiver plants through soil, but they are often modified, accumulated, leached, or taken up by the target plants [1].

Allelochemials produced by weeds may differ by weed species and environmental factors such as light, ultraviolet, ionizing radiation, read and far-red light, minerals, drought stress, fungi, pathogens, and insects [1]. Some fungi and insects exploited allelochemicals as energies by using their allelochemical degrading enzymes [5]. However, allelopathic agents are usually chemicals derived from secondary metabolites or waste products from the primary metabolic pathways in plants [26]. Allelochemicals do not play a role in the primary metabolism essential for plant growth and development, but are produced when they are under biotic and abiotic stresses [17,27]. There may have over 10,000 known secondary metabolites in higher plant and fungi [27], but the possible number of secondary chemicals in nature may reach 400,000 [1]. The interaction of weed allelochemicals in the environment is rather complicated because their transformation to the receiver plants depending on certain environmental conditions and soil factors. Allelochemicals from weeds, similar to other secondary metabolites, are commonly phenolics, terpenoids, alkaloids, coumarins, tannins, flavonoids, steroids, and quinones [28]. However, only certain compounds have been reported to be allelopathic in plant tissues, such as juglone, scopoletin, hydroxamic acid, and sorgoleone [18].

The utilization of weed allelochemicals for weed and pest management is potent. However, the direct use of these compounds is not possible, because of their fast degradation and the isolation of these allelochemicals is complicated and costly. Therefore, the appropriate use of weeds in the crop-weed system, especially legume weeds, in an ecological and sustainable agriculture production, should be a key topic for weed researchers and agronomists. On the other hand, the syntheses of weed allelochemicals' derivatives are helpful to reduce cost, and may find compounds with novel modes of action for the development of bioactive pesticides.

\section{Allelochemicals of some specific weeds}

\section{Bidens pilosa}

This is a noxious invasive weed, distributing widely in the tropics and subtropics, and becoming a problem in many countries. In Japan, this weed is strengthening its distribution and dominated strongly in uncultivated and abandoned land, and where native species is replaced by human purposes. Despite several pharmaceutical properties of this weed have been reported, but its invasive strength causes more problems than its benefits. We observed that the plant extracts of $B$. pilosa exerted strong suppression against growth of Raphanus sativus and E. crus-galli, and several phytopathogens [28]. Fifteen phenolics including pyrocatechin, salicylic acid, $p$-vinylguaiacol, dimethoxyphenol, eugenol, 4-ethyl-1,2-benzenediol, iso-vanillin, 2-hydroxy-6-methylbenzaldehyde, vanillin, vanillic acid, $p$-hydroxybenzoic acid, protocatechuic acid, $p$-coumaric acid, ferulic acid, and caffeic acid were identified in the leaves, stems, and roots of the weeds. Of them, caffeic acid accounted for a rather high quantity (117.4-350.3 $\mu \mathrm{g} / \mathrm{g})$ in all plant parts than other compounds $(2.5-37.1 \mu \mathrm{g} / \mathrm{g})$ [28]. However, the release rates of these compounds as well as their fates in the soil have not been clarified yet. In addition, phenylheptatriyne was also detected from this plant and demonstrated to act as an allelochemical [29]. 


\section{Echinochloa crus-galli}

This is one among the most noxious weeds worldwide and is causing troublesome in agricultural production. A number of allelochemicals were found in the root exudates at the germination stage. The extract of root exudates showed selective influence against monocot and dicot plants [5]. More recently, we found that this weed released a number of allelochemicals into paddy soil to suppress growth of rice and monochoria (Monochoria vaginalis), but showed much lower inhibition against growth of itself. Allelochemicals presented in barnyardgrass soil were phenols, terpenes, and fatty acids [5]. However, identification of growth inhibitors other than these substances, which involved in the inhibitory activities of barnyardgrass, has not been succeeded yet.

Yamamoto et al. [30] reported that barnyardgrass inhibited the growth of cockscomb (Celosia cristata L. var. kunze), timothy (Phleumpratense L.), cress (Lepidium sativum), amaranth (Amaranthus viridis), rice (Oryza sativa), lettuce (Lactuca sativa), and barnyardgrass itself. p-Hydroxymandelic acid, an allelochemical exuding from young barnyard grass roots, significantly reduced the growth of rice at 59.5-178.6 mM. It was also re-discovered the presence of $p$-hydroxymandelic acid in barnyardgrass infested soil [31].

\section{Imperata cylindrica}

This weed species is also one among the most problematic weeds worldwide, especially in upland. I. cylindrica (cogongrass) is very difficult to control as the weed extends by its strong rhizome. Many efforts have been attempted to minimize this weed distribution, but very sporadic successes have been approached. We identified and quantified from the rhizome of I. cylindrica possessed about 40 compounds belonging to phenols, phenolic acids, fatty acids, steroids, and lactones [32]. Chemicals in root leachates and those released by the weed rhizome to soil of cogongrass were also examined. It was found that even though the released amount and the quantity of growth inhibitors detected in the soil was in much lower levels than those observed in the rhizome, but their quantities are lethal enough to suppress growth of most upland weeds. Many allelochemicals derived from this weed exhibited strong plant growth inhibition at low concentration [32]. Several phenolic acids were identified in this weed including vanillic acid, $p$-coumaric acid, syringic acid, scopolin, scopoletin, chlorogenic acid, iso-chlorogenic acids $[33,34,35]$.

\section{Parthenium hysterophorus}

Parthenium (P. hysterophorus L.), native to Mexico, US, and Argentina, has been an invasive weed in more than 30 countries worldwide [36]. In Asia, the weed is an emerging threat weed in India, Nepal, Bangladesh, Pakistan, Vietnam, China, and Sri Lanka [37]. It is a dominant weed in Australia, Southeast Asia, Western Africa, Caribbean countries, and Latin America [38,39]. P. hysterophorus showed strong inhibition on emergence of various crops and weeds [40]. Allelochemicals were found in every plan part of this invasive weed, and major components included sesquiterpene and lactones, parthenin, coronopilin, phenolic acids (caffeic, vanillic, ferulic, chlorogenic, $p$-hydroxybenozic, $p$-coumaric acids), and anisic acid [41,42,43,44]. Other constituents are tannins, saponins, cardiac glycosides, seteroids [45], and volatile compounds [46]. In general, Parthenium weed contain toxins from chemical group of $\mathrm{C}_{15}$ [47]. The lactones in Parthenium contain 35 lactones of the pseudoguaicinolide and xanthanolide skeletal types [47].

\section{Ageratum conyzoides}

This weed is originated from mid-America, now widely spreads in the subtropics and tropics [48]. It is a destructive weed of arable land, caused problems in crop production [49]. This weed is highly adaptable and spreads vegetatively through stolons [50]. A. conyzoides exhibited strong 
inhibition against emergence of other weeds in fields [51]. Allelochemicals isolated from this weed consisted of essential oils [52], ageratochromene and its hydroxyl derivatives, and flavones [53,54], and the two dimmers [55], and phenolic acids included $p$-coumaric acid, sinapic acid, and benzoic acid [51].

\section{Ambrosia trifida}

This weed is native to North America and is an invasive species [56], and was reported invading throughout China by its strong production of plant biomass and suppressing all associated species [55]. A. trifida is among the most economically destructive weeds and its infestation interferes with the growth and establishment of crop plants. Particularly in wheat fields, A. trifida often caused significant reduction of growth and yield of wheat [57]. Since this weed invaded the fields, crop production was reduced, particularly wheat, corn, and soybean [57,58]. Carotane sesquiterpenes, thiarubrines, thiophenes $[59,60]$, and essential oils $[61,62]$ were identified from this noxious weed. Some among them were plant growth inhibitors [57,61]. In the A. trifida infested soil, two carotene-type sesquiterpenes were identified and acted as plant growth inhibitors [55]. These allelochemicals were attributed to the weed residues, not from root exudates [57]. The presence of other allelochemicals in this weed remains obscure.

\section{Lantana camara}

This is a perennial shrub, native to the tropical America and West Africa, and it was introduced into Asia as an ornamental garden plant, eventually escaped from cultivation, and became invasive [55]. This weed invades in natural forests or plantations, pastures, grasslands, along river banks and roadsides, and in agricultural fields [49]. In agricultural production, L. camara leads to a significant reduction in crop productivity. L. camara is ranked as one of the world's 10 worst weeds among the top 100 invasive species [63]. Lantadenes A and B were allelochemicals found in the decomposed plants of L. camara. Other chemicals from this invasive weed included monoterpenes and sesquiterpenes, triterpenes, irridoid glycosides, furanonaphtho-quinones, flavonoids, and phenyl ethanoid glycosides $[64,65]$.

Parasitic weeds

Parasitic weeds are serious problems in agriculture, causing large crop reduction in many parts of the world. The most common species are Striga spp., Orobanche spp., and Cuscuta spp. The Striga spp. parasitize mainly tropical cereal crops, such as maize, sorghum, pearl millet, and upland rice [66,67]. Whereas Orobanche spp. parasitize more-temperate climate crops, such as sunflower, tomato, tomato, tobacco, rape seed, and legumes [67]. Unlike Striga spp. and Orobanche spp., that are selective on only several plant species, Cuscuta spp. can invade plants as diverse as green algae (Chara spp.), fern, gymnosperms, and a wide variety of angiosperms [68]. Chemical constituents from Striga were flavonoids, apigenin and derivatives, luteolin, chrysoeriol, acatetin, caffeic acid sugar esters, verbascoside and derivatives, norsesquiterpene, and blumenol [69]. Interestingly, germination of Striga spp. and Orobanche spp. are induced by strigolactones such as alectrol and orobanchol from red clover (Trifolium pretense) stimulated germination of $O$. minor [70]. In Cuscuta hygrophilae, terpenes, long-chain fatty acids, phenols, phenolic acids, and lactones were identified and reported to involve in the suppression on other weeds of the parasitic weed [71].

\section{Other weeds}

Mechanism of action of these allelochemicals against crops includes the interference with cell division and membrane permeability [72], hormone induced growth [73], reduction of photosynthesis, water conductance [74], soil microflora [75], stomata opening, and interference with protein and nucleic acid metabolism [76]. 
Important allelochemicals detected in different weed species are:

(i) Phenolic acids: Antennaria microphylla [77], Avena fatua [78], Bromus japonicas [79], Camelina alyssum [80], Chenopodium album [81], Chromolaena odorata [82], Cirsium arvense [83], Cyperus esculentus [84], Digitaria sanguinalis [85] [86], Echinops echinatus [87], Erica spp. [88,89,90], Euphorbia corrollata [91], Galium mollugo [92], Lantana camara [93], Melilotus alba [94], Parthenium hysterophorus [43,95], Pteridium aquilinum [96,97], Plantago occidentalis [98]; Rorippa sylvestris [99,100], Rumex crispus [101], Salsola kali [102], Sasa cernua [103], Sporobolus pyramidatus [104], Sorghum halepense [91,105], Vulpia spp. [106], Xanthium strumarium [107].

(ii) Long chain fatty acids: Polygonum aviculare [75].

(iii) Monoterpenes, triterpenes, terpenes, sesquiterpenes: Ambrosia psilostachya [91], Artemisia absinthium [108], A. апnиa [78], A. herba-alba [109], Ambrosia trifida [62], Bidens pilosa [28], Chenopodium ambrosioides [110], Cherodendrum viscosum [111], Cyperus rotundus [112], Digitaria sanguinalis [113], Salvia apiana, S. leucophylla, S. millifera [114,115], Lantana camara $[64,65]$.

(iv) Alkaloids: Datura stramonium [116,117], Delphinium ajacis [118], Chromolaena odorata [82], Lantana camara [64,65].

(v) Lactones: Ambrosia cumanensis [119], Centaurea maculosa and C. repens [120],121], Parthenium hysterophorus $[41,47,95]$.

(vi) Flavonoids: Abutilon theophrasti [122], Galium mollugo [92], Pluchea laneolata [123], Ruta graveolens [124].

(vii) Glycosides: Phleum pretense [125], Polygonum orientalis [126], Lantana camara [64,65].

(viii) Other compounds: free amino acids (Abutilon theophrasti) [122], agrostemin (Agrostema githago) [127], allyl isothiocyanate (Brassica nigra) [128], oxalic acid (Chenopodium murale) [110], abscisic acid and phaseic acid (Croton bonphlandianum) [129], arthaquinone (Polygonum sachalinese) [130], aromatic compounds (Salvia reflexa) [131], thiophenes and benzofurans (Tagetes patula) [132].

\section{Implications in development of natural pesticides}

Allelochemicals from plants, including weeds, have been referred as future natural pesticides or nature's herbicides in action. Allelochemicals are natural origin and they can be degraded fast after incorporating into environment, are acknowledged to be safer than synthetic pesticides. However, allelochemicals with strong biological activities often have complicated chemical structures, resulted in complicated extraction and the synthesis of their derivatives for the development of novel pesticides is costly. Allelochemicals are selective at low doses and they have no long-term environmental effects as they can be degraded by natural decomposing microorganisms [1]. However, to date, no synthetic herbicide from allelopathic background has been made [133]. Various broadleaf crops and weed species were found to susceptible to AAL-toxins, a natural metabolites produced by Alternaria alternate f. sp. lycopersici, the pathogen that cause stem canker of tomato [1]. Monocots are generally ineffective to AAL-toxin and Abbas et al. [134] proposed that they could be exploited for selective weed control. Parthenin, a sesquiterpene lactone from Parthnium hysterophorus strongly reduced germination and seedling growth of billy goat weed but no effect was found on wheat [135]. Despite present developed pesticides are of microbial (fungi or bacteria origin) derivatives or products [18], but allelochemicals from weeds are still promising and needs elaboration toward development of natural pesticides. 


\section{Potential in pest management}

Many weeds have been reported to inhibit emergence of other weeds, such as dodder [71], $A$. conyzoides [51,52,54], P. hysterophorus [40,42,46,49], I. cylindrica [5], B. pilosa [28], Chenopodium murale [136], and barnyadgrass [5,31]. The incorporation of weed biomass, for instance A. conyzoides and B. pilosa, to paddy fields reduced paddy weed emergence to $70 \%$ and promoted rice yield up to $20 \%$ [137]. The allelopathic property of L. camaran can be exploited to control water hyacinth. The highly inhibitory compounds that are responsible for the mortality of water hyacinth were subsequently identified as pentacylic triterpenoids, lantadenes A and B [55].

Some weeds can be promising sources to control parasitic nematodes. The presence of $A$. trifida contributed to lower number of the parasitic nematodes, such as Aphelenchoides, Filenchus, and Tylenchus [138]. The intercropping of A. conyzoides enhanced the amount of predator mites (Amblyseius spp.) in the citrus orchard [139]. These predatory mites are effective natural enemies of the pest, citrus red mite (Panonychus citri) [52]. The volatile chemicals from A. conyzoides were described to promote infestation of Amblyseius spp. [52]. P. hysterophorus showed strong inhibition on growth of some pathogens like Fusarium oxysporum, Aspergillus niter, and Drechslera hawaiinsis. The antifungal property of this weed was attributed to parthenin, a major phytoalexin of this weed [47]. A. conyzoides also stunted the spore germination of soil pathogenic fungi including Phytopththora cirophthora, Pythium aphanidermatum, and Fusarium solani, and flavonones A, B, $\mathrm{C}$, and ageratochrome and its two dimers A, B exhibited strong inhibition against growth of weeds and plant fungi [54]. B. pilosa also exhibited excellent antifungal capacity and the essential oils of the weed played a critical role [28]. The bactericidal and fungicidal activity of $A$. trifida against six bacterial strains and two fungal strains were reported [62].

\section{Conclusions}

Interaction of weed allelochemicals is an interesting topic which may help to extend knowledge on the allelopathic mechanism of weeds. The use weeds for weed and pest management strategy in the establishment of a sustainable agriculture production is promising. To separate a single allelochemical from weeds is a laborious work, but it can clarify how allelochemicals play a role in the weed-weed, and weed-crop interactions. For instance, some allelochemicals may play as a plant growth inhibitors, but in contrast, the others may act as plant growth promoters. Therefore, understanding the role of allelochemicals in the interactions among crops, weeds, bacteria, fungi, and insects therefore enhance the efficacy of pest management in crop production. In addition, allelopathic effects of weeds against certain crops should be further studied to exploit effectively weed allelochemicals. In addition, further searches for novel and potent allelochemicals with stronger bioactivities should also been conducted to utilize the allelopathic potential of weeds in greater extents.

\section{References}

[1] J.R. Qasem, C.L. Foy, Weed allelopathy, its ecological impact and future prospects: a review, J. Crop Prod. 4 (2001) 43-119. doi:10.1300/J144v04n02_02.

[2] S.R. Eskelsen, G.D. Crabtree, The role of allelopathy in buckwheat (Fagopyrum sagittatum) inhibition of Canada thistle (Cirsium arvense), Weed Sci. 43 (1995) 70-74. doi:10.1614/WT-09-050.1.

[3] K.L. Kalburtji, A. Gagianas, Effects of sugarbeet as a preceding crop on cotton, J. Agron. Crop Sci. 178 (1997) 59-63. doi: 10.1111/j.1439-037X.1997.tb00351.x 
[4] J.S. Sauerborn, Legumes used for weed control in agro-ecosystems in the tropics, Plant Res. Dev. 50 (1999) 74-82.

[5] T.D. Xuan, I.M. Chung, T.D. Khanh, S. Tawata, Identification of phytotoxic substances from early growth of barnyardgrass (Echinochloacrus-galli) root exudates, J. Chem. Ecol. 32 (2006a) 895-906. doi:10.1007/s10886-006-9035-x.

[6] T.D. Xuan, A.A. Elzaawely, F. Deba, M. Fukuta, S. Tawata, Mimosine in Leucaena as a potent bio-herbicide, Agron. Sustain. Dev. 26 (2006b) 89-97. doi:10.1051/agro:2006001.

[7] H.P. Bais, R. Vepachedu, R. Callaway, Allelopathy and exotic plant invasion: from molecules and genes to species, Sci. 301 (2003) 1377-1380. doi:10.1126/science.327.5967.781-b.

[8] S.O. Duke, A.C. Blair, F.E. Dayan, R.D. Johnson, K.M. Meepagala, D. Cook, J. Bajsa, Is (-) catechin a novel weapon of spotted knapweed (Centaurea stoebe)?, J. Chem. Ecol. 35 (2009) 142-153. doi:10.1007/s 10886-008-9587-z.

[9] U.P. Singh, V.B. Pandey, K.N. Singh, R.D.N. Singh, Antifungal activity of some new flavones and flavone glycosides of Echinops echinatus, Can. J. Bot. 66 (1998) 1901-1903. doi: $10.1139 / \mathrm{b} 88-260$.

[10] O. Spring, U. Rodon, F.A. Macias, Sesquiterpenes from noncapitate glandular trichomes of Helianthus annus, Phytochem. 31 (1992) 1541-1544. doi:10.1016/0031-9422(92)83102-5.

[11] F.A. Tomas-Barberan, A.D. Msonthi, K. Hostettmann, Antifungal epicuticular methylated flavonoids from Helichrysum nitens, Phytochem. 27 (1998) 75-755. doi:10.1016/0031-9422(88)84087-1.

[12] A.G. Gonzalez, T. Abad, I.A. Jiménez, A.G. Ravelo, J.G. L.Z. Aguiar, L.S. Andrés, M. Plasencia, J.R. Herrera, L. Moujir, A first study of antibacterial activity of diterpenes from some Salvia species (Lamiaceae), Biochem. Syst. Ecol. 17 (1989) 293-296. doi: 10.1016/0305-1978(89)90005-7.

[13] L. Kasasian, Control of Orobanche, Int. J. Pest Manage. 19 (1973) 368-371. doi:10.1080/09670877309412782.

[14] H.H. Linke, H. Schnell, M.C. Saxena, Factors affecting the seed bank of Orobanche crenata in fields under lentil based cropping systems in northern Syria, in: J.K. Ransom, L.J. Musselman, A.D. Worsham, C. Parkers (Eds.), Proceedings of the $5^{\text {th }}$ International Symposium on parasitic weeds. Nairobi: CIMMYT, 1991, pp. 321-327.

[15] R. Labrada, R. Perez, Non-chemical control methods for Orobanche ramose, Agrotenica de Cuba. 20 (1988) 35-40.

[16] B. Bouhatous, P. Jacquard, The effect of combination of hosts on infection capacity of Orobanche crenata Forks, in: A.H. Pieterse, J.A.C. Verkei, S.J. Borg (Eds), Biology and management of orobanche, proceedings of the third international workshop on orobanche and related striga research. Amsterdam, The Netherlands, Royal Tropical Institute, 1994, pp. 320-333.

[17] E.L. Rice, Allelopathy. New York, Academic Press, 1974, pp. 352. doi:10.1007/BF02869951.

[18] A.R. Putnam, C.S. Tang, Allelopathy: state of science, in: A.R. Putnam, C.S. Tang (Eds), The Science of Allelopathy. New York, John Wiley and Sons, Inc., 1986, pp. 1-19.

[19] J.V. Lovett, J. Levitt, Allelochemicals in a future agriculture, in: B. Stonehouse (ed), Biological Husbandry. London, Butterworth, 1981, pp. 169-181.

[20] W.W. Fletcher, R.C. Kirkwood, A growth inhibitor found in Centaurea spp, Can. J. Plant Sci. 43 (1982) 475-481. doi: 10.4141/cjps63-098.

[21] J.R. Qasem, Allelopathic effect of white top (Lepidium draba) on wheat and barley, Allelopathy J. 1 (1994) 29-40. 
[22] S.D. Kanchan, J. Chandra, Pollen allelopathy - a new phenomenon, New Phytol. 84 (1980) 739-746. doi:10.1111/j.1469-8137.1980.tb04786.x.

[23] J.R. Qasem, Aqueous extract effect of nettle-leaved goosefoot (Chenopodium murale L.) on wheat and barley, Res. J. Apeppo Univ. 14 (1990) 37-53.

[24] J. Arines, E. Vieitez, J.L.F. Mantilla, In: Herbicides and Plant Growth Regulators. London, Granada, 1974, pp. 93-99.

[25] D.T. Bell, D.E. Koeppe, Noncompetitive effects of giant foxtail on the growth of corn, Agron. J. 64 (1972) 321-325. doi:10.2134/agronj1972.00021962006400030019x.

[26] D.A. Levin, The chemical defenses of plants to pathogens and herbivores, Annu. Rev. Ecol. Syst. 7 (1976) 121-159. doi: 10.1146/annurev.es.07.110176.001005.

[27] T. Swain, Secondary compounds as protective agents, Annu. Rev. Plant Phys. 28 (1977) 479-501. doi:10.1146/annurev.pp.28.060177.002403.

[28] F. Deba, T.D. Xuan, M. Yasuda, S. Tawata, Herbicidal and fungicidal activities and identification of potential phytotoxins from Bidens pilosa L. var. radiata Scherff, Weed Biol. Manag. 7 (2007) 77-83. doi:10.1111/j.1445-6664.2007.00239.x.

[29] G. Campbell, J.D.H. Lambert, T. Arnason, G.H.N. Towers, Allelopathic properties of alpha-terthienyl and phenylheptatriyne, naturally occurring compounds from species of Asteraceae, J. Chem. Ecol. 8 (1982) 961-972. doi: 10.1007/BF00987662.

[30] T. Yamamoto, K. Yokotani-Tomita, S. Kosemura, S. Yamamura, K. Yamada, K. Hasegawa, Allelopathic substance exuded from a serious weed, germinating barnyardgrass (Echinochloa crus-galli $\quad$ L.) roots, J. Plant Growth Regul. 18 (1999) 65-67. doi:10.1007/PL00007050.

[31] Y. Gu, H.B. Li, C.H. Kong, Allelopathic potential of barnyardgrass on rice and soil microbes in paddy, Allelopathy J. 21 (2008) 389-395.

[32] T.D. Xuan, T. Toyama, M. Fukuta, T.D. Khanh, S. Tawata, Chemical interaction in the invasiveness of cogongrass (Imperata cylindrica (L.) Beauv.), J. Agr. Food Chem. 57 (2009) 9448-9453. doi:10.1021/jf902310j.

[33] A.S. Abdul-Wahab, F.A.G. Al-Naib, Inhibitional effects of Imperata cylindrica (L.), Bull. Iraqi Nat. Hist. Mus. Pub. 5 (1972) 17-24.

[34] J.H.H. Eussen, Isolation of growth inhibitory substances from alang-alang (Imperata cylindrica (L.)). in: J.H.H. Eussen (Ed.), Studies on tropical weed Imperata cylindrica (L.) Beauv. var. major. Utrecht, Drukkerij Elinkwijk Bv, 1978.

[35] J.H.H. Eussen, G.J. Niemann, Zeitschrift fur Pflanzenphysiol 102:263, cited by J.V. Lovett (1986) Allelopathy: The Australian experience, in: A.R. Putnam, C.S. Tang (Eds.), The Science of Allelopathy. New York, John Wiley and Sons, 1986, pp. 75-99.

[36] S.W. Adkins, A. Shabbir, Biology, ecology and management of the invasive pathenium weed (Parthenium hysterophorus L.), Pest Manag. Sci. 70 (2014) 1023-1029. doi: 10.1002/ps.3708

[37] K.K. Barman, V.P. Singh, R.P. Dubey, P.K. Singh, A. Dixit, A.R. Sharma, Challenges and opportunities in weed management under a changing agricultural scenario, in: Recent Advances in Weed Management. Springer, New York Heidelberg Dordrecht London, 2014, pp. 365-390. doi: 10.1007/978-1-4939-1019-9_16.

[38] S.W. Adkins, S.C. Navie, K. Dhlileepan, Parthenium weed in Australia: research progress and prospects, in: T.V. Ramachadra Prasad, H.V. Nanjappa, R. Devendra (Eds.), Proceedings of the Second International Conference on Parthenium Management. University of Agricultural Sciences, Bangalore, India, 2005, pp. 11-27. 
[39] L. Nigatu, A. Hasen, J. Sharma, S.W. Adkins, Impact of Parthenium hysterophorus on grazing land communities in North-Eeastern Ethiopia, Weed Biol. Manag. 10 (2010) 143-152. doi: 10.1111/j.1445-6664.2010.00378.x

[40] A. Tanveer, A. Khaliq, H.H. Ali, G. Mahajan, B.S. Chauhan, Interference and management of parthenium: the world's most important invasive weed, Crop Prot. 68 (2015) 49-59. doi: 10.1016/j.cropro.2014.11.005

[41] H.P. Singh, Effect of parthenin - a sesquiterpene lactone from Parthenium hysterophorus, on early growth and physiology of Ageratum conyzoides, J. Chem. Ecol. 28 (2002) 2169-2179. doi: 10.1023/A:1021089013754

[42] D.R. Batish, H.P. Singh, D.B. Saxena, R.K. Kohli, Weed suppressing ability of parthenin-a sesquiterpene lactone from Parthenium hyterophorus. N. Z., Plant Prot. 55 (2002) 218-221.

[43] D.R. Batish, Assessment of Parthenium against some weeds, A. Naturforsch 62 (2007) 367-372.

[44] C.F. Reinhardt, R.G. Belz, K. Hurle, Role of the allelochemical parthenin in the invasive strategy of the alient plant Parthenium hysterophorus L., South Afr. J. Bot. 75 (2009) 417-418. doi:10.1016/j.sajb.2009.02.097.

[45] N. Ambiye, V. Golatkar, Phytochemical analysis of Lantana camara and Parthenium hysterophorus, Bioinfolet. 7 (2010) 135-136.

[46] C. Yebing, Allelopathic effects of Parthenium hysterophorus L. volatilos its chemical components, Allelopathy J. 27 (2011) 217.

[47] K. Jai, C. Abhishek, K. Ajita, B. Satish, J. Disha, Inhibitory potential of parthenin a sesquiterpene lactone against Fusarium oxysporum, Aspergillus niger and Drechslera hawaiiensis, Intel. J. Res. Biosci. 5 (2016) 72-75.

[48] W. Roder, S. Phenchanh, B. Keoboulapha, Weeds in slash and burn rice fields in northern Laos, Weed Res. 37 (1997) 111-119. doi: 10.1046/j.1365-3180.1996.d01-6.x.

[49] R.K. Kohli, D.R. Batish, H.P. Singh, K.S. Dogra, Status, invasiveness and environmental threats of three tropical American invasive weeds (Parthenium hysterophorus L., Ageratum conyzoides L., Lantana camara L.) in India, Biol. Invasions. 8 (2006) 1501-1510. doi: 10.1007/s10530-005-5842-1.

[50] A.L. Okunade, Ageratum conyzoides L. (Asteraeae), Fitoterapia. 73 (2002) 1-16. doi:10.1016/S0367-326X(01)00364-1.

[51] T.D. Xuan, T. Shinkichi, N.H. Hong, T.D. Khanh, I.M. Chung, Assessment of phytotoxic action of Ageratum conyzoides L. (billy goat weed) on weeds, Crop Prot. 23 (2004) 915-922. doi:10.1016/j.cropro.2004.02.005.

[52] C.H. Kong, F. Hu, X. Xu, M. Zhang, W. Liang, Volatile allelochemicals in the Ageratum conyzoides intercropped citrus orchard and their effects on mites Amblyseius newsami and Panonychus citri, J. Chem. Ecol. 31 (2005) 2193-2203. doi: 10.1007/s10886-005-6085-4.

[53] W.S. Bowers, T. Ohta, J.S. Cleere, P.A. Marsella, Discovery of insect anti-juvenile hormone in plants, Science. 193 (1976) 542-547. doi: 10.1126/science.986685.

[54] C.H. Kong, Allelochemicals and their transformations in the Ageratum conyzoides intercropped citrus orchard soils, Plant Soil. 264 (2004) 149-157. doi: 10.1023/B:PLSO.0000047759.65133.fa.

[55] C.H. Kong, Ecological pest management and control by using allelopathic weeds (Ageratum conyzoides, Ambrosia trifida, and Lantana camara) and their allelochemicals in China, Weed Biol. Manag. 10 (2010) 73-80. doi: 10.1111/j.1445-6664.2010.00373.x.

[56] J.H. Kil, K.C. Shim, K.A. Park, K. Kim, Inhibitory effects of Ambrosia trifida L. on the development of root hairs and protein patterns of radicle, Intel. J. Biol. Biomol. Agri. Food Biotech. Engin. 8 (2014) 608-611. 
[57] C.H. Kong, P. Wang, C.X. Zhang, M.X. Zhang, F. Hu, Herbicidal potential of allelochemicals from Lantana camara against Eichlornia crasspipes and the alga Microsystis aeruginosa, Weed Res. $46 \quad$ (2006) 290-295. doi: 10.1111/j.1365-3180.2006.00509.x.

[58] M.M. Williams, J.B. Masiunas, Functional relationships between giant ragweed (Ambrosia trifida) interference and sweet corn yield and ear traits, Weed Sci. 54 (2006) 948-953.

[59] E. Bloszyk, U. Rychlewska, B. Szczepanska, M. Holub, Sesquiterpene lactones of Ambrosia artemisiifolia L. and Ambrosia trifida L. species, Collect. Czech Chem. Commu. 57 (1992) 1092-1102. doi: 10.1135/ccc19921092.

[60] T.S. Lu, J.P. Felix, V. David, H.F. Nikolaus, Sesquiterpenes and thiarubrines from Ambrosia trifida and its transformed roots, Phytochem. 33 (1993) 113-116. doi: 10.1016/0031-9422(93)85405-G.

[61] P. Wang, W.J. Liang, C.H. Kong, Y. Jiang, Allelopathic potentials of volatile allelochemicals from Ambrosia trifida L. on other plants, Allelopathy J. 15 (2005) 131-136.

[62] P. Wang, C.H. Kong, C.X. Zhang, Chemical composition and antimicrobial activity of the essential oil from Ambrosia trifida L., Molecules 11 (2006) 549-555. doi:10.3390/11070549.

[63] L.G. Holm, D.L. Plucknett, J.V. Pancho, J.P. Herberger, The World's Worst Weeds: Distribution and Ecology. Krieger, Malabar, FL, 1991.

[64] C.B. Gentle, J.A. Duggin, Allelopathy as a competitive strategy in persistent thicklets of Lantana camara L. in three Australian forest communities, Plant Ecol. 132 (1997) 85-96. doi: 10.1023/A:1009707404802.

[65] E.L. Ghisalberti, Lantana camara L. (Verbenaceae), Fitoterapia 71 (2000) 467-486. doi:10.1016/S0367-326X(00)00202-1.

[66] M.C. Press, J.D. Scholes, C.R. Riches, Current status and future prospects for management of parasitic weeds (Striga and Orobanche), in: C.R. Riches (Ed.), the World's Worst Weeds. British Crop Protection Council, Brighton, UK, 2001, pp. 71-90.

[67] R. Matusova, R. Kumkum, F.W.A. Verstappen, M.C.R. Franssen, M.H. Beale and H.J. Bouwmeester, The strigolactone germination stimulants of the plant-parasitic Striga and Orobanche spp. are derived from the carotenoid pathway, Plant Physiol. 139 (2005) 920-934. doi: http://dx.doi.org/10.1104/pp.105.061382.

[68] J.H. Dawson, L.J. Musselman, P. Wolswinkel, I. Dorr, Biology and control of Cuscuta, Rev. Weed Sci. 6 (1994) 265-317.

[69] W. Huang, S.B. Wu, Y.L. Wang, Z.Y. Guo, E.J. Kennelly, C.L. Long, Chemical constituents from Striga asiatica and its chemotaxonomic study, Biochem. System Ecol. 48 (2013) 100-106. doi:10.1016/j.bse.2012.10.010.

[70] T. Yokota, H. Sakai, K. Okuno, K. Yoneyama, Y. Takeuchi, Alectrol and orobanchol, Germination stimulants from Orobanche minor, from its host red clover, Phytochem. 49 (1998) 1967-1973. doi:10.1016/S0031-9422(98)00419-1.

[71] T.D. Khanh, L.C. Cong, T.D. Xuan, S.J. Lee, D.S. Kong, and I.M. Chung, Weed-suppressing potential of dodder (Cuscuta hygrophilae) and its phytotoxic constituents, Weed Sci. 56 (2008) 119-127. doi: http://dx.doi.org/10.1614/WS-07-102.1.

[72] C.H. Muller, Inhibitory terpenes volatilized from Salvia shrubs, Bull. Torrey Bot. Club 92 (1965) 38-45. doi:10.2307/2483311.

[73] J. Wurzoburger, Y. Leshem, Physiological action of the germination inhibitor in the husk of Aegilops hotschyi Bioss, New Phytol. $68 \quad$ (1969) 337-341. doi:10.1111/j.1469-8137.1969.tb06445.x. 
[74] C.E. Colton, F.A. Einhellig, Allelopathic mechanisms of velvet leaf (Abutilon theophrasti Medic, Malvaceae) on soybean, Soil Sci. Soc. Am. J. 41 (1980) 903-908. doi: $10.2307 / 2442868$.

[75] I.S. Alsaadawi, E.L. Rice, Allelopathic effects of Polygonum aviculare L. I. Vegetational patterning, J. Chem. Ecol. 8 (1982) 993-1009. doi:10.1007/BF00987881.

[76] M. Vikherkova, Influence of active substances from rhizome of wheatgrass on growth and water balance of flax, in: A.M. Grodzinsky (Ed.), Physiological-biochemical basis of plant interaction in phytocenoses. Keiv, Naukova Dumka, 1970, pp. 135-140.

[77] G.D. Manners, D.S. Galitz, Allelopathy of small everlasting (Antennaria microphylla): Identification of constituents phytotoxic to leafy spurge (Euphorbia esula), Weed Sci. 34 (1986) 8-12.

[78] J. Lydon, J.R. Teasdale, P.K. Chen, Allelopathic activity of annual wormwood (Artemisia annua) and the role of artemisinin, Weed Sci. 45 (1997) 807-811.

[79] E.L. Rice, R.L. Parenti, Inhibition of nitrogen-fixing and nitrifying bacteria by seed plants. VI. Inhibitors produced by Bromus japonica Thunb, Southwest Nat. 12 (1967) 97-103. doi: $10.2307 / 1934928$.

[80] G. Grummer, H. Beyer, The influence exerted by species of Camelina on flax by means of toxic substances, Symposium of the British Ecological Society 1 (1960) 13-157.

[81] M.A.B. Mallik, R. Puchala, F.A. Grosz, A growth-inhibitory factor from lambquarters (Chenopodium album), J. Chem. Ecol. 20 (1994) 957-967. doi:10.1007/BF02059590.

[82] S.R. Ambika, Allelopathic interference of Chromolaena odorata (L.), in: R.M. King, H. Robinson (Eds.), Second world congress on allelopathy: critical analysis and future prospect. Lakehead University, Thunder Bay, Ontario, Canada, Abstract no 49, 1999.

[83] F. Hussain, T.W. Khan, A. Hussain, Allelopathic effects of Cirsium arvense (L.) Scop, in: I. Ilahi, F. Hussain (Eds.), Modern trends of plant science research in Pakistan. Proceedings in third national conference of plant scientists. Department of Botany, Peshawar, University of Peshawar, 1987, pp. 24-28.

[84] R.S. Tames, M.D. Gesto, E. Vieitez, Growth substances isolated from tubers of Cyperus esculentus var. aureus, Physiol. Plant 28 (1973) 95-200. doi:10.1111/j.1399-3054.1973.tb01175.x.

[85] E.L. Rice, W.T. Penfound, L.M. Rohrbaugh, Seed dispersal and mineral nutrition in succession in abandoned fields in central Oklahoma, Ecol. 41 (1960) 224-228. doi:10.2307/1931958.

[86] R.L. Parenti, E.L. Rice, Inhibitional effects of Digitaria sanguinalis and possible role in old-field succession, Bull. Torrey Bot. Club 96 (1969) 70-78. doi:10.2307/2484009.

[87] S.R. Soni, K. Mohnot, Presence of an autotoxic factor in fruit carp of Echinops echinatus Roxb, J. Curr. Biosci. 5 (1988) 101-104.

[88] M.C. Salas, E. Vieitez, Activated de crecimiento de Ericaceae, Anales de Edafocogia y Agrobilogia 31 (1972) 1001-1009.

[89] A. Ballester, J.M. Albo, E. Vieitez, The allelopathic potential of Erica scoparia L., Oecol. 30 (1977) 55-6. doi:10.1007/BF00344891.

[90] Carballeira, A. Cuervo, Seasonal variation in allelopathic potential of soils from Erica australis L. healthland, Acta. Oecol. 1 (1980) 345-353.

[91] E.L. Rice, Inhibition of nitrogen-fixing and nitrifying bacteria by seed plants. IV. The inhibitors produced by Ambrosia elatior L. and Ambrosia psilostachya D. C., Southwest Nat. 10 (1965) 248-255. doi:10.2307/1934928. 
[92] S. Kohmuenzer, Botanical and chemical studies of the collective species Gallium mollugo with reference to karyotypes growing in Poland.VI. Effects of extracts and some other chemical components of Galium molugo on the germination of seeds and growth of selected plant, Dissert. Pharm. Pharma. 17 (1965) 369-379.

[93] H.P. Singh, D.R. Batish, R.K. Kohli, Autotoxicity: concept, organisms, and ecological significance, Crit. Rev. Plant Sci. 18 (1999) 757-772. doi:10.1080/07352689991309478.

[94] A.G. Winter, New physiological and biological aspects in the interrelationships between higher plants, Sym. Soc. Exp. Biol. 15 (1961) 229-244.

[95] S.D. Kanchan, Jayachandra, Pollen allelopathy - a new phenomenon, New Phytol. 84 (1976) 739-746.

[96] A.D.M. Glass, The allelopathic potential of phenolic acids associated with the rhizosphere of Pteridium aquilinum, Can. J. Bot. 54 (1976) 2440-2444. doi:10.1139/b76-259.

[97] D.C. Whitehead, H. Dibb, R.D. Hartley, Phenolic compounds in soil as influenced by the growth of different plant species, J. App. Ecol. 19 (1982) 579-588. doi:10.2307/2403490.

[98] F.A. Al-Naib, E.L. Rice, Allelopathic effects of Plantanus occidentalis, Bull. Torrey Bot. Club 98 (1971) 75-82. doi:10.2307/2483770.

[99] J. Kawabata, 8-methylsulfinyloctyl isothiocyanate as allelochemical candicate from Rorippa sylvestris Besser, Agric. Biol. Chem. 53 (1989) 3361-3362. doi:10.1271/bbb1961.53.3361.

[100] A. Yamane, J. Fujikura, H. Ogawa, J. Mizutani, Isothiocyanates as allelopathic compounds from Rorippa indica Hiern (Cruciferae) roots, J. Chem. Ecol. 18 (1992) 1941-1954. doi:10.1007/BF00981918.

[101] F.A. Einhellig, J.A. Rasmussen, Allelopathic effects of Rumex crispus on Amaranthus retroflexus, grain sorghum and field corn, Am. Midl. Nat. 90 (1973) 79-86. doi: $10.2307 / 2424268$.

[102] M.A.K. Lodhi, Germination and decreased growth of Kochia scoparia in relation to its autoallelopathy, Can. J. Bot. 57 (1979) 1083-1088. doi:10.1139/b79-132.

[103] H.H. Li, Allelopathy of Sasa cernua, J. Chem. Ecol. 18 (1992) 1785-1796. doi:10.1007/BF02751103.

[104] J.A. Rassmussen, E.L. Rice, Allelopathic effects of Sporobolus pyramidatus on vegetational patterning, Am. Midl. Nat. 86 (1971) 309-326. doi:10.2307/2423626.

[105] A.S. Abdul-Wahab, E.L. Rice, Plant inhibition by Johnson grass and its possible significance in old field succession, Bull. Torrey Bot. Club 94 (1967) 486-497. doi:10.2307/2483566.

[106] M. An, J.E. Pratley, T. Haig, Allelochemical dynamic of decaying Vulpia residues, and their corresponding biological activity, in: R.M. King, H. Robinson (Eds.), Second world congress on allelopathy: critical analysis and future prospect. Lakehead University, Thunder Bay, Ontario, Canada, Abstract no 5, 1999.

[107] Inam, F. Hussain, F. Bano, Allelopathic effects of Pakistani weeds: Xanthium strumarium L., Pak. J. Sci. Ind. Res. 30 (1987) 530-533.

[108] G. Grumer, The role of toxic substances in the interrelationships between higher plants, in: F.L. Milthorpe (Ed.), Mechanisms in biological bompetition. New York, Academic Press, 1961, pp. 219-228.

[109] J. Friedman, Allelopathy in desert ecosystems, in: G.R. Waller (Ed.), Allelochemicals: Role in Agriculture and Forestry, ACS Symposium Series 330. Washington, DC, American Chemical Society, 1987, pp. 53-68. doi: 10.1021/bk-1987-0330.ch006.

[110] S.C. Datta, K.N. Ghosh, Allelopathy in 2 species of Chenopodium inhibition of germination and seedling growth of certain weeds. Acta. Soc. Bot. Pol. 56 (1987) 257-270. doi:10.5586/asbp.1987.025. 
[111] S.C. Datta, S.D. Chakarbarti, Allelopathy in Clerodendrum viscosum: Inhibition of mustard (Brassica) germination and seedling growth, Comp. Physiol. Ecol. 7 (1982) 1-7.

[112] K. Komai, K. Ueki, Chemical properties and behavior of polyphenolic substances in purple nutsedge (Cyperus rotundus L.), Weed Res. 20 (1975) 66-71.

[113] Zhou, Chemical constituents of the essential oils of wild oat and crabgrass and their effects on the growth and allelochemical production of wheat. Weed Biol. Manag. 13 (2013) 62-69. doi: $10.1111 / \mathrm{wbm} .12010$.

[114] W.H. Muller, C.H. Muller, Volatile growth inhibitors produced by Salvia species. Bull. Torrey Bot. Club 91 (1964) 327-330. doi:10.2307/2483297.

[115] C.H. Muller, W.H. Muller, B.L. Haines, Volatile growth inhibitors produced by shrubs, Sci. 143 (1964) 471-473. doi:10.1126/science.143.3605.471.

[116] J.V. Lovett, Allelopathic potential of Datura stramonium L. (Thorn-apple), Weed Res. 21 (1981) 165-170. doi:10.1111/j.1365-3180.1981.tb00112.x.

[117] J.V. Lovett, W.C. Potts, Primary effects of allelochemicals of Datura stramonium L., Plant Soil 98 (1987) 137-144. doi:10.1007/BF02381734.

[118] G.R. Waller, H. Burstrom, Diterpenoid alkaloids as plant growth inhibitors, Nature 222 (1969) 576-578. doi:10.1038/222576a0.

[119] S. Del Amo, A.L. Anaya, Effect of some sesquiterpene lactones on the growth of certain secondary topical specie, J. Chem. Ecol. 4 (1978) 305-313. doi:10.1007/BF00989339.

[120] L.J. Locken, R.G. Kelsey, Cnicin concentrations in Centaurea maulosa spotted knapweed. Biochem. Syst. Ecol. 15 (1987) 313-320. doi:10.1016/0305-1978(87)90005-6.

[121] K.L. Stevens, G.B. Merrill, Sesquiterpene lactones and allelochemicals from Centaurea, in: A.C. Thompson (Ed.), The Chemistry of Allelopathy. Washington DC, American Chemical Society, 1985, pp. 83-98. doi: 10.1021/bk-1985-0268.ch006.

[122] J.B. Gressel, L.G. Holm, Chemical inhibition of crop germination by weed seeds and nature of inhibition by Abutilon theophrasti, Weed Res. 4 (1964) 44-53. doi:10.1111/j.1365-3180.1964.tb00266.x.

[123] Inderjit, K.M.M. Dakshini, Investigation of some aspects of chemical ecology of cogongrass, Imperata cylindrica (L.) Beauv., J. Chem. Ecol. 17 (1991) 343-352. doi:10.1007/BF00994337.

[124] G. Aliota, Germination of radish (Raphanus sativus L.) seeds in presence of rue (Ruta graveolens L.) infusion: a cellular perspective, in: R.M. King, H. Robinson (Eds.), Second world congress on allelopathy: critical analysis and future prospect. Lakehead University, Thunder Bay, Ontario, Canada, Abstract no.47, 1999.

[125] C.J. Avers, R.H. Goodwin, Studies on roots. IV. Effects of coumarin and scopoletin on the standard root growth pattern of Phleumpratense, Am. J. Bot. 43 (1956) 61-620. doi: $10.2307 / 2438877$.

[126] S.C. Datta, A.K. Chatterjee, Allelopathy, in Polygoum orientale: inhibition of seed germination and seedling growth of mustard, Comp. Physiol. Ecol. 5 (1980) 54-59.

[127] Gajic, Study of the quantitative and qualitative improvement of wheat yield through agrostemin as an allelopathic factor, Fragmenta Herbologica Jugoslavica 63 (1976) 1-5.

[128] D.T. Bell, C.H. Muller, Dominance of California annual grassland by Brassica nigra, Am. Midl. Nat. 90 (1973) 277-299. doi:10.2307/2424453.

[129] S.C. Datta, S.P. Sinha-Roy, Phytotoxic effects of Croton bonplandianum Baill. on weedy associates, Vegetatio. 30 (1975) 157-163. doi:10.1007/BF02389704.

[130] M. Inoue, Allelochemical from Polygnum sachalinese FR. Schm. (Polygonaceae), J. Chem. Ecol. 18 (1992) 1833-1840. doi:10.1007/BF02751107. 
[131] J.V. Lovett, J.A. Lynch, Studies of Salvia reflexa Hornem. 1. Possible competitive mechanisms, Weed Res. 19 (1979) 351-357. doi:10.1111/j.1365-3180.1986.tb00707.x.

[132] C.S. Tang, C.K. Wat, G.H.N. Towers, Thiophenes and benzofurans in the undisturbed rhizosphere of Tagetes patula L., Plant Soil 98 (1987) 93-97. doi:10.1007/BF02381730.

[133] D.T. Patterson, Allelopathy, in: N.D. Camper (Ed.), Research Methods in Weed Science, 3rd edn. Champain, IL: Southern Weed Science Society, 1986, pp. 111-134.

[134] H.K. Abbas, T. Tanaka, S.O. Duke, C.D. Boyette, Susceptibility of various crop and weed species to AAL-toxin, a natural herbicide, Weed Technol. 9 (1995) 125-130.

[135] D.R. Batish, Studies on herbicidal activity of parthenin - a constituent of Parthenium hysterophorus towards bill-goat weed, Curr. Sci. 73 (1997) 369-371.

[136] S. Dmitrovic, Morpho-histological and bioherbicidal evaluation of wild-type and transformed hairy roots of goosefoot, South. Afr. J. Bot. 96 (2015) 53-61. doi:10.1016/j.sajb.2014.11.002.

[137] T.D. Xuan, S. Tawata, T.D. Khanh, I.M. Chung, Biological control of weeds and plant pathogens in paddy rice by exploiting plant allelopathy: an overview, Crop Prod. 24 (2005) 197-206. doi:10.1016/j.cropro.2004.08.004.

[138] W. Wang, X.R. Zhu, W.Z. Liu, Influence of ragweed (Ambrosia trifida) on plant parasitic nematodes, J. Chem. Ecol. 24 (1998) 1707-1714. doi:10.1023/A:1020824813741.

[139] W.G. Liang, M.D. Huang, R.J. Prokopy, Influence of citrus orchard ground cover plants on arthropod communities in China: a review, Agri. Eco. Environ. 50 (1994) 29-37. doi:10.1016/0167-8809(94)90122-8. 